\title{
TINGKAT PENGETAHUAN GURU SEKOLAH MENENGAH PERTAMA NEGERI TENTANG BULLYING DI KOTA PEKANBARU
}

\author{
Nurul Wahyuni ${ }^{1}$, Sri Wahyuni ${ }^{2}$, Siti Rahmalia Hairani Damanik ${ }^{3}$ \\ ${ }^{1,2,3}$ Fakultas Keperawatan Universitas Riau \\ Jalan Pattimura No.9 Pekanbaru, Riau \\ Kode Pos 28131, Indonesia \\ Email: nurulwahyuni.keasun@gmail.com
}

\begin{abstract}
ABSTRAK
Bullying merupakan salah satu bentuk kekerasan yang dilakukan secara berulang oleh seseorang atau sekelompok orang yang lebih kuat dengan tujuan untuk menyakiti dan akan menimbulkan dampak bagi korban maupun pelaku. Guru sebagai tenaga pendidik yang berinteraksi langsung dengan siswa memiliki peranan penting, yaitu dalam upaya pencegahan yang didasari oleh pengetahuan guru terhadap bullying itu sendiri. Penelitian ini bertujuan untuk mengetahui tingkat pengetahuan guru Sekolah Menengah Pertama Negeri tentang bullying di Kota Pekanbaru dengan desain penelitian deskriptif dan metode survei. Sampel penelitian adalah 154 orang responden yang diambil berdasarkan kriteria inklusi menggunakan teknik purposive sampling. Analisa yang digunakan adalah analisa univariat untuk mengetahui distribusi frekuensi karakteristik responden dan tingkat pengetahuan guru. Hasil penelitian menunjukkan bahwa tingkat pengetahuan guru SMPN tentang bullying di Kota Pekanbaru pada umumnya adalah baik (76\%-100\%), yaitu sebanyak 121 responden $(78,6 \%)$. Guru diharapkan dapat meningkatkan pengetahuan dengan berpartisipasi aktif dalam sosialisasi atau seminar terkait isu terbaru bullying di sekolah.
\end{abstract}

Kata kunci: Bullying, Guru, Pengetahuan

\section{ABSTRACT}

Bullying is one form of violence carried out repeatedly by a person or group of people who are stronger with the intention to hurt and will have an impact for victims and perpetrators. Teachers as educators who interact directly with the students has an important roles, namely in prevention efforts based on the knowledge of teachers to bullying itself. This study aims to determine the level of knowledge of junior high school teachers about bullying in the city of Pekanbaru with descriptive research designs and survey methods. The samples were 154 respondents drawn based on inclusion criteria using techniques purposive sampling. The analysis used univariate analysis to determine the frequency distribution characteristics of respondents and the level of the teacher's knowledge. The results of the study showed that the level of knowledge of the junior high school teachers about bullying in Pekanbaru City in general was good (76\%100\%), as many as 121 respondents. (78.6\%). Teachers are expected to increase knowledge by actively participating in socialization or seminars related to the latest issues of bullying at school.

Keywords : Bullying, Knowledge, Teacher

\section{PENDAHULUAN}

Bullying (perundungan) merupakan proses pelecehan dan tindakan kekerasan yang disengaja dan dilakukan oleh seseorang atau lebih terhadap orang lain secara berulang-ulang dengan maksud untuk menyakiti atau menimbulkan perasaan tertekan. Bullying mengakibatkan korban berada dalam keadaan tidak mampu mempertahankan diri untuk melawan tindakan negatif yang telah diterima (Arya, 2018; Soedjatmiko, 2013; Susanti, 2018). Arya (2018) menambahkan bahwa bullying terjadi karena adanya ketidakseimbangan kekuatan (power imbalance) antara pelaku dan korban bullying. 
Nurul Wahyuni ${ }^{1}$, Sri Wahyuni ${ }^{2}$, Siti Rahmalia Hairani Damanik ${ }^{3}$, Tingkat Pengetahuan Guru Sekolah Menengah Pertama Negeri tentang Bullying di Kota Pekanbaru

Bullying (perundungan) merupakan fenomena yang tersebar di seluruh dunia dan tingkatnya bervariasi di berbagai studi. Soedjatmiko, Nurhamzah, Maureen dan Wiguna (2013) menyimpulkan bahwa prevalensi bullying diperkirakan $8-50 \%$ di beberapa negara Asia, Amerika, dan Eropa. Menurut National Center for Eductional Statistic (2016 dalam National Bullying Prevention Center, 2017) menyatakan bahwa lebih dari satu dari setiap lima $(20,8 \%)$ siswa melaporkan di bully (rundung). Kejadian bullying di dunia berdasarkan data yang dihimpun dari childhelplineineternastional.org menunjukkan adanya tren kenaikan frekuensi bullying dari tahun 2009 sebanyak 79.110 kasus hingga tahun 2012 sebesar 113.698 kasus (Arya, 2018).

Bullying dapat terjadi di berbagai tempat, mulai dari lingkungan pendidikan atau sekolah, tempat kerja, rumah, lingkungan sekitar, dan tempat bermain (Maliki, 2009). Penelitian Yayasan Semai Jiwa Amini (2008) di 3 kota besar di Indonesia, yaitu Yogjakarta, Surabaya dan Jakarta, mencatat perilaku bullying sebesar $66,1 \%$ terjadi di SLTP dengan kategori tertinggi kekerasan psikologis yaitu pengucilan, dan peringkat kedua adalah kekerasan verbal (mengejek) dan fisik (memukul) (SEJIWA, 2008). Priyatna (2010) membagi bullying dalam empat kategori, yaitu bullying fisik, bullying verbal, bullying sosial dan cyber bullying. Penelitian oleh Soedjatmiko (2013) menyimpulkan bahwa kategori bullying yang tersering adalah bullying fisik (93,8\%). Pendapat tersebut sejalan dengan penelitian yang dilakukan oleh Putri (2015) terhadap 83 siswa Sekolah Menengah Atas menunjukkan bahwa sebagian besar perilaku bullying yang dilakukan adalah secara fisik yaitu sebanyak orang 46 responden $(55,4 \%)$.

Bullying memberikan dampak negatif terhadap pelaku dan korban. Dampak bullying terbesar dialami oleh korban bullying. Anak korban bullying cenderung untuk mengalami gejala somatisasi lebih tinggi dibanding dengan anak-anak yang lain. Sakit kepala berulang hingga sulit tidur merupakan contohcontoh gejala somatisasi yang dapat terjadi (Saptandari, 2013). Selain itu, anak korban bullying akan mengalami kesulitan dalam bergaul, merasa takut datang ke sekolah sehingga absensi mereka tinggi dan tertinggal pelajaran, dan mengalami kesulitan berkonsentrasi dalam mengikuti pelajaran sehingga akan berdampak pada prestasi belajarnya (Dwipayanti \& Indrawati, 2014; SEJIWA, 2008). Semai Jiwa Amini (SEJIWA) menambahkan bahwa hal yang paling ekstrim mengenai dampak psikologis dari bullying yaitu munculnya gangguan psikologis seperti depresi dan memiliki keinginan untuk bunuh diri serta munculnya gejala gangguan stres pasca trauma (SEJIWA, 2008).

Prevalensi bullying di sekolah semakin meningkat dari tahun ke tahun. Informasi 
yang diperoleh peneliti dari beberapa surat kabar menyatakan bahwa Komisi Perlindungan Anak Indonesia (KPAI) mencatat sekitar 253 kasus bullying sejak tahun 2011 hingga 2016. Bullying yang disebut KPAI sebagai bentuk kekerasan di sekolah, mengalahkan tawuran pelajar, diskriminasi pendidikan, ataupun aduan pungutan liar. Kasus bullying kembali tercatat pada tahun 2017, terdapat sebanyak 45 pengaduan korban bully dan 60 pengaduan pelaku bully. Data terbaru dari KPAI pertanggal 30 Mei 2018 menyebutkan bahwa terdapat 22,4\% (36 kasus) merupakan pengaduan anak korban bully dan kekerasan dan 25,5\% (41 kasus) pengaduan anak pelaku kekerasan dan bully (Kumparan, 2017; Sindonews, 2018; Vemale, 2018).

Bullying pada siswa di sekolah terjadi disebabkan oleh beberapa faktor diantaranya adalah faktor sekolah, faktor perilaku teman sebaya dan faktor keluarga. Faktor tersebut dapat mengakibatkan anak berpotensi menjadi lebih agresif, pemberani, suka melawan, dan mencari dukungan sosial untuk melakukan bullying kepada teman sekolah yang mereka anggap lemah dan mudah untuk dirundung (Susanti, 2018; Tumon, 2014; Usman, 2013). Usman (2013) manambahkan faktor lain yang dapat menjadi pemicu perilaku bullying pada remaja yaitu jenis kelamin, tipe kepribadian anak, dan kepercayaan diri.

Fenomena bullying ibarat gunung es, kasus yang mencuat terlihat sedikit, namun faktanya sangat banyak, mengakar, terwariskan dari generasi ke generasi. Bullying sebagian besar tidak diketahui atau disadari oleh guru di sekolah. Guru sering terlena oleh "kesan" remeh fenomena bullying, sehingga mengesampingkan dampak dan bahaya bullying terhadap korban maupun pelaku bullying (Astuti, 2008; Surilena, 2016). Perilaku bullying kurang diperhatikan di sekolah, karena dinilai tidak memiliki pengaruh besar terhadap siswanya (Surilena, 2016), padahal siswa tidak dapat belajar apabila berada dalam keadaan tertekan, terancam dan ada yang menindasnya setiap hari (Smokowski, 2010).

Nugroho (2011) mengidentifikasi bahwa guru sebagai agen kunci perubahan dalam penanganan perilaku. Guru yang memiliki kesadaran untuk menolak bullying serta pengetahuan dan keterampilan yang memadai dalam menangani bullying akan berpengaruh pada keberhasilan intervensi terhadap bullying di sekolah (Saptandari, 2013). Namun pengetahuan guru tentang bully dan dampaknya belum sepenuhnya disadari oleh guru (Nugroho, 2011; Sugiariyanti, 2010). Hal ini dapat terlihat pada survei yang dilakukan oleh SEJIWA (dalam Sugiariyanti, 2010) yang menunjukkan bahwa 18,3\% guru (1 dari 5 guru) menganggap bahwa mengintimidasi dan mengejek adalah hal yang biasa dalam kehidupan siswa sekolah dan tidak perlu diributkan. Sebanyak 27\% guru (1 dari 4 
Nurul Wahyuni ${ }^{1}$, Sri Wahyuni ${ }^{2}$, Siti Rahmalia Hairani Damanik ${ }^{3}$, Tingkat Pengetahuan Guru Sekolah Menengah Pertama Negeri tentang Bullying di Kota Pekanbaru

guru) berpendapat bahwa sesekali mengalami penindasan tidak akan berdampak buruk pada kondisi psikologis siswa.

Sementara itu, belum ada penelitian terkait tingkat pengetahuan guru tentang bullying di sekolah di Kota Pekanbaru. Berdasarkan fenomena diatas, peneliti tertarik untuk mengetahui "tingkat pengetahuan guru Sekolah Menengah Pertama Negeri tentang perilaku bullying di Kota Pekanbaru"

\section{METODE PENELITIAN}

Penelitian ini dilaksanakan di Sekolah Menengah Pertama Negeri (SMPN) di Kecamatan Marpoyan Damai Kota Pekanbaru pada bulan September tahun 2018 sampai dengan bulan Februari tahun 2019. Penelitian ini menggunakan menggunakan metode kuntitatif dengan desain penelitian deskriptif survei. Populasi dalam penelitian ini adalah seluruh guru SMPN di Kecamatan Marpoyan Damai. Sampel pada penelitian ini sebanyak 154 guru dari 6 SMPN di Kecamatan Marpoyan Damai. Teknik sampling yang digunakan yaitu purposive sampling dengan kriteria inklusi yaitu guru tetap SMPN yang berada di Kecamatan Marpoyan Damai dan bersedia menjadi responden penelitian.

Peneliti memulai penelitian dengan mengunjungi SMPN yang terdekat dengan lokasi peneliti yaitu dimulai dengan SMPN Madani Pekanbaru, SMPN 37, SMPN 21, SMPN 8, SMPN 34, dan SMPN 25. Alat pengumpul data yang digunakan pada penelitian ini yaitu kuesioner tentang pengetahuan guru terkait bullying yang terdiri dari 15 pernyataan. Komponen yang diteliti meliputi pengertian, karakteristik pelaku dan korban, bentuk, penyebab dan dampak bullying.

Sebelum kuesioner penelitian ini disebarkan kepada responden, kuesioner ini telah teruji validitas dan reliabilitasnya. Uji validitas instrumen ini melibatkan 20 guru SMPN yang tidak dijadikan sebagai sampel penelitian, guru SMPN tersebut merupakan guru SMPN 20 di Kecamatan Tampan Kota Pekanbaru. Berdasarkan hasil uji validitas didapatkan validitas pengetahuan diperoleh nilai $r$ hitung $>r$ tabel yakni 0,412-0,676> 0,378 dan uji reliabilitas diperoleh nilai $\alpha>r$ tabel, yaitu $0,967>0,6$. Peneliti dengan bantuan wakil ketua humas dan kurikulum masing-masing SMPN menyebar kuesioner kepada guru di sekolah.

\section{HASIL PENELITIAN}

\section{Karakteristik Responden}

Karakteristik responden yang diperoleh pada penelitian ini adalah:

Tabel 1

Distribusi karakteristik responden

\begin{tabular}{lcc}
\multicolumn{1}{c}{ Karakteristik } & n=154 & \% \\
\hline Umur & & \\
17-25 tahun (Remaja akhir) & 2 & 1,3 \\
26-35 tahun (Dewasa awal) & 26 & 16,9 \\
36-45 tahun (Dewasa akhir) & 60 & 39 \\
46-55 tahun (Lansia awal) & 52 & 33,8 \\
56-65 tahun (Lansia akhir) & 14 & 9,1 \\
\hline Jenis Kelamin & & \\
Laki-laki & 33 & 21,4 \\
Perempuan & 121 & 78,6 \\
\hline
\end{tabular}




\begin{tabular}{lcc}
\hline \multicolumn{1}{c}{ Karakteristik } & $\mathbf{n = 1 5 4}$ & $\mathbf{\%}$ \\
\hline Pendidikan & & \\
SMA & 8 & 5,2 \\
Sarjana & 136 & 88,3 \\
Magister & 7 & 4,5 \\
Lainnya (Diploma) & 3 & 1,9 \\
\hline Agama & & \\
Islam & 145 & 94,2 \\
Kristen & 9 & 5,8 \\
\hline Pengalaman kerja menjadi & & \\
guru & & \\
< 6 tahun & 17 & 11 \\
- 10 tahun & 27 & 17,5 \\
$>10$ tahun & 110 & 71,4 \\
\hline
\end{tabular}

Berdasarkan tabel 1 didapatkan data bahwa guru SMPN di Kecamatan Marpoyan Damai Kota Pekanbaru mayoritas berada pada rentang usia 36-45 tahun (dewasa akhir) sebanyak 60 orang (39\%), sebagian besar guru adalah perempuan sebanyak 121 orang $(78,6 \%)$, jenis pendidikan mayoritas adalah sarjana sebanyak 136 orang (88,3\%), agama Islam merupakan agama sebagian besar guru yaitu sebesar 145 orang $(94,2 \%)$, pengalaman kerja menjadi guru mayoritas adalah lebih dari 10 tahun yaitu sebanyak 110 orang $(71,4 \%)$.

\section{Pengetahuan guru SMPN tentang bullying di Kota Pekanbaru}

Tabel 2

Distribusi tingkat pengetahuan guru terhadap setiap komponen

\begin{tabular}{|c|c|c|c|c|c|c|}
\hline \multirow{3}{*}{ Komponen } & \multicolumn{6}{|c|}{ Tingkat pengetahuan } \\
\hline & \multicolumn{2}{|c|}{ Baik } & \multicolumn{2}{|c|}{ Cukup } & \multicolumn{2}{|c|}{ Kurang } \\
\hline & $\mathbf{n}$ & $\%$ & $\mathbf{n}$ & $\%$ & $\mathbf{n}$ & $\%$ \\
\hline $\begin{array}{l}\text { Pengertian } \\
\text { bullying }\end{array}$ & 107 & 69,5 & 39 & 25,3 & 8 & 5,2 \\
\hline $\begin{array}{l}\text { Karakteristik } \\
\text { korban maupun } \\
\text { pelaku bullying }\end{array}$ & 92 & 59,7 & 0 & 0 & 62 & 40,3 \\
\hline Bentuk bullying & 54 & 35,7 & 57 & 37 & 43 & 27,9 \\
\hline
\end{tabular}

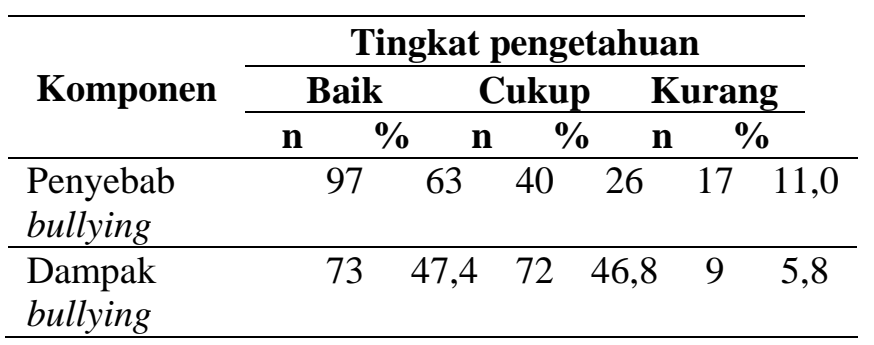

Berdasarkan tabel 2 didapatkan data bahwa distribusi tingkat pengetahuan guru untuk komponen pengetahuan tentang pengertian bullying mayoritas adalah baik sebanyak 107 orang (69,5\%), pengetahuan guru tentang karakteristik pelaku dan korban bullying sebagian besar adalah baik sebanyak 92 orang $(59,7 \%)$, pengetahuan guru tentang bentuk bullying sebagian besar adalah cukup sebanyak 57 orang (37\%), pengetahuan guru tentang penyebab bullying mayoritas adalah baik, sebanyak 97 orang $(63 \%)$, dan pengetahuan guru tentang dampak bullying sebagian besar adalah baik, sebanyak 73 orang $(47,4 \%)$.

Tabel 3

Tingkat pengetahuan guru SMPN tentang bullying di Kota Pekanbaru

\begin{tabular}{lcc}
\hline $\begin{array}{c}\text { Kriteria tingkat } \\
\text { pengetahuan }\end{array}$ & $\mathbf{n}$ & $\boldsymbol{\%}$ \\
\hline Baik $(76 \%-100 \%)$ & 121 & 78,6 \\
Cukup $(56 \%-75 \%)$ & 29 & 18,8 \\
Kurang $(<56 \%)$ & 4 & 2,6 \\
\hline Jumlah & $\mathbf{1 5 4}$ & $\mathbf{1 0 0}$ \\
\hline
\end{tabular}

Berdasarkan tabel 3 didapatkan data bahwa dari 154 guru SMPN di Kecamatan Marpoyan Damai Kota Pekanbaru yang diteliti, tingkat pengetahuan guru SMPN tentang bullying di Kota pekanbaru mayoritas 
Nurul Wahyuni ${ }^{1}$, Sri Wahyuni ${ }^{2}$, Siti Rahmalia Hairani Damanik ${ }^{3}$, Tingkat Pengetahuan Guru Sekolah Menengah Pertama Negeri tentang Bullying di Kota Pekanbaru

adalah baik (76\%-100\%), yaitu sebanyak 121

orang $(78,6 \%)$.
3. Crosstab tingkat pengetahuan tentang bullying berdasarkan karakteristik responden

Tabel 4

Crosstab tingkat pengetahuan tentang bullying berdasarkan karakteristik responden $(n=154)$.

\begin{tabular}{|c|c|c|c|c|c|c|c|c|}
\hline \multirow{3}{*}{ Karakteristik } & \multicolumn{4}{|c|}{ Tingkat Pengetahuan } & \multirow{2}{*}{\multicolumn{2}{|c|}{ Kurang }} & \multirow{2}{*}{\multicolumn{2}{|c|}{ Total }} \\
\hline & \multicolumn{2}{|c|}{ Baik } & \multicolumn{2}{|c|}{ Cukup } & & & & \\
\hline & $\mathbf{n}$ & $\%$ & $\mathbf{n}$ & $\%$ & n & $\%$ & $\mathbf{n}$ & $\%$ \\
\hline \multicolumn{9}{|l|}{ Usia } \\
\hline 17-25 tahun (Remaja akhir) & 2 & 1,3 & 0 & 0 & 0 & 0 & 2 & 1,3 \\
\hline \multirow{3}{*}{ Karakteristik } & \multicolumn{6}{|c|}{ Tingkat Pengetahuan } & \multirow{2}{*}{\multicolumn{2}{|c|}{ Total }} \\
\hline & & & & & & & & \\
\hline & $\mathbf{n}$ & $\%$ & $\mathbf{n}$ & $\%$ & $\mathbf{n}$ & $\%$ & $\mathbf{n}$ & $\%$ \\
\hline 26-35 tahun (Dewasa awal) & 20 & 13 & 5 & 3,2 & 1 & 0,6 & 26 & 16,9 \\
\hline 36-45 tahun (Dewasa akhir) & 47 & 30,5 & 12 & 7,8 & 1 & 0,6 & 60 & 39 \\
\hline 46-55 tahun (Lansia awal) & 40 & 26 & 11 & 7,1 & 1 & 0,6 & 52 & 33,8 \\
\hline 56-65 tahun (Lansia akhir) & 12 & 7,8 & 1 & 0,6 & 1 & 0,6 & 14 & 9,1 \\
\hline \multicolumn{9}{|l|}{ Jenis Kelamin } \\
\hline Laki-laki & 20 & 13 & 11 & 7,1 & 2 & 1,3 & 33 & 21,4 \\
\hline Perempuan & 101 & 65,6 & 18 & 11,7 & 2 & 1,3 & 121 & 78,6 \\
\hline \multicolumn{9}{|l|}{ Pendidikan } \\
\hline SMA & 6 & 3,9 & 2 & 1,3 & 0 & 0 & 8 & 5,2 \\
\hline Sarjana & 105 & 68,2 & 27 & 17,5 & 4 & 2,6 & 136 & 88,3 \\
\hline Magister & 7 & 4,5 & 0 & 0 & 0 & 0 & 7 & 4,5 \\
\hline Lainnya (Diploma) & 3 & 1,9 & 0 & 0 & 0 & 0 & 3 & 1,9 \\
\hline \multicolumn{9}{|l|}{ Agama } \\
\hline Islam & 115 & 74,7 & 26 & 16,9 & 4 & 2,6 & 145 & 2,6 \\
\hline Kristen & 6 & 3,9 & 3 & 1,9 & 0 & 0 & 9 & 5,8 \\
\hline \multicolumn{9}{|l|}{$\begin{array}{l}\text { Pengalaman kerja menjadi } \\
\text { guru }\end{array}$} \\
\hline$<6$ tahun & 14 & 9,7 & 2 & 1,3 & 1 & 0,6 & 17 & 11 \\
\hline 6-10 tahun & 19 & 12,3 & 7 & 4,5 & 1 & 0,6 & 27 & 17,5 \\
\hline$>10$ tahun & 88 & 57,1 & 20 & 8,5 & 2 & 1,8 & 110 & 71,4 \\
\hline
\end{tabular}

Tabel 4 diatas menunjukkan crosstab tingkat pengetahuan tentang bullying berdasarkan karakteristik responden adalah sebagai berikut. Guru dengan tingkat pengetahuan baik paling banyak berada dalam rentang usia 36-45 tahun (dewasa akhir) sebanyak 47 orang (30,5\%), sedangkan berdasarkan karaktersitik jenis kelamin tingkat pengetahuan baik paling banyak adalah guru perempuan sebanyak 101 orang $(65,6 \%)$. Guru dengan tingkat pengetahuan baik berdasarkan karakteristik pendidikan dan kategori tingkat pendidikan mayoritas berturut-turut adalah sarjana dan pendidikan tinggi, yaitu sebesar 105 orang $(68,2 \%)$ dan 115 orang $(74,7 \%)$. Berdasarkan karakteristik agama, guru dengan tingkat pengetahuan yang baik berturut-turut adalah Islam sebanyak 115 orang $(74,7 \%)$ dan Melayu sebanyak 58 orang (37,7\%). Guru dengan tingkat pengetahuan baik berdasarkan karakteristik pengalaman kerja menjadi guru paling banyak adalah guru dengan pengalaman 
kerja lebih dari 10 tahun yaitu sebanyak 88 orang $(57,1 \%)$.

\section{PEMBAHASAN}

\section{Karakteristik Responden}

\section{a. Usia}

Hasil penelitian didapatkan bahwa sebagian besar guru berada dalam rentang usia 36-45 tahun, yaitu sebanyak 60 orang (39\%). Menurut Super (1957 dalam Coertse \& Schepers, 2004) menjelaskan bahwa perkembangan karir pada rentang usia tersebut termasuk kedalam tahap establishment. Pada tahap ini individu memasuki dunia kerja yang sesuai dengan dirinya dan bekerja keras untuk mempertahankan pekerjaan tersebut. Selain itu, masa ini merupakan masa paling produktif dan kreatif. Hal ini didukung dengan data yang diperoleh dari Pusat Data dan Statistik Pendidikan dan Kebudayaan tahun ajaran 2017/2018 yang menyatakan bahwa guru SMPN dalam rentang usia 30-39 tahun dan 4049 tahun berturut-turut merupakan kategori rentang usia terbanyak pertama dan ketiga dengan jumlah sebanyak 1260 orang (35\%) dan 596 orang $(20,3 \%)$ dari jumlah keseluruhan guru sebanyak 2929 orang (Pusat Data dan Statistik Pendidikan dan Kebudayaan, 2018).

\section{b. Jenis Kelamin}

Hasil penelitian terhadap 154 guru SMPN di kecamatan Marpoyan Damai Kota Pekanbaru didapatkan bahwa mayoritas adalah perempuan, yaitu sebanyak 121 orang
$(78,6 \%)$. Pendapat ini sejalan dengan data yang diperoleh dari Statistik Pendidikan tahun ajaran 2017/2018 yang menyatakan bahwa guru SMPN dengan jenis kelamin perempuan (1406 orang) lebih mendominasi dibandingkan dengan guru dengan jenis kelamin laki-laki (1193 orang) (Pusat Data Statistik Pendidikan dan Kebudayaan, 2018). Pendapat ini didukung oleh penelitian Mulyani (2014) yang menyatakan bahwa mayoritas guru di SMPN adalah perempuan sebesar $65,3 \%$.

Lips et all (1978 dalam Handoyo 1992) menyebutkan bahwa tingginya jumlah guru berjenis kelamin perempuan disebabkan karena perempuan lebih superior untuk berhubungan dengan orang lain dan mempunyai kemampuan untuk mengendalikan situasi-situasi anatar pribadi dibandingkan laki-laki. Selain itu, perempuan juga memiliki kemampuan lebih baik dalam hal persahabatan dan lebih sensitif untuk memperhatikan kebutuhan-kebutuhan dan perasaan orang lain serta perempuan lebih efektif dalam hal mendidik atau mengasuh dibandingkan lakilaki. Kemampuan-kemampuan pada diri perempuan ini sangat diperlukan dalam proses pendidikan dikarenakan hubungan antar pribadi (antara guru dengan siswa) sangat diperlukan untuk suksesnya pendidikan itu sendiri.

\section{c. Pendidikan}

Menurut Undang-Undang Nomor 20 tahun 2003 tentang Sistem Pendidikan Nasional menyatakan bahwa pendidikan dapat 
Nurul Wahyuni ${ }^{1}$, Sri Wahyuni ${ }^{2}$, Siti Rahmalia Hairani Damanik ${ }^{3}$, Tingkat Pengetahuan Guru Sekolah Menengah Pertama Negeri tentang Bullying di Kota Pekanbaru

ditempuh melalui jalur formal, nonformal dan informal. Jenjang pendidikan formal terbagi menjadi tiga, yaitu pendidikan dasar, pendidikan menengah dan pendidikan tinggi.

Pendidikan tinggi mencakup program pendidikan diploma, sarjana, magister, spesialis, dan doktor yang diselenggarakan oleh perguruan tinggi. Hasil penelitian ini menunjukkan bahwa program pendidikan mayoritas responden pada penelitian ini adalah sarjana, yaitu sebanyak 136 orang (88,3\%). Menurut Undang-undang Nomor 14 tahun 2005 tentang guru dan dosen menyebutkan bahwa guru sebagai tenaga pendidik profesional wajib memiliki kualifikasi akademik, kompetensi, sertifikat pendidik, sehat jasmani dan rohani, serta memiliki kemampuan untuk mewujudkan tujuan pendidikan nasional. Kualifikasi akademik diperoleh melalui pendidikan tinggi program sarjana atau program diploma empat. Hal ini sejalan dengan penelitian yang dilakukan oleh Purwati (2013) yang menyatakan bahwa mayoritas guru SMPN memiliki jenjang pendidikan terakhir Strata 1 (S1) atau Sarjana, yaitu sebesar 86,9\%. Mulyani (2014) juga sependapat bahwa jenjang pendidikan terakhir yang paling banyak dimiliki oleh guru SMPN adalah Sarjana dengan persentase sebesar $81,4 \%$.

Hasil penelitian ini juga menunjukkan masih adanya guru dengan program pendidikan dibawah Sarjana atau program diploma empat, yaitu program pendidikan
SMA sebanyak 8 orang $(5,2 \%)$ dan Diploma sebanyak 3 orang (1,9\%). Pusat Data dan Statistik Pendidikan dan Kebudayaan tahun 2017 juga menyampaikan bahwa sebanyak 2637 guru SMP (14,55\%) memiliki program pendidikan dibawah S1 atau Sarjana (Pusat Data dan Statistik Pendidikan dan Kebudayaan, 2017).

Notodiharjo (1990 dalam Sumakta, 2015) yang menyatakan bahwa minat melanjutkan studi ke perguruan tinggi dipengaruhi oleh pertimbangan yang bersifat sosial ekonomi dan mempunyai hubungan yang sistematis dan signifikan dengan beberapa varibel, salah satunya adalah umur. Menurut peneliti, masih adanya guru dengan program pendidikan dibawah sarjana atau dilpoma empat dapat terjadi dikaitkan dengan usia responden. Pada penelitian ini mayoritas guru dengan pendidikan menengah berada dalam kategori usia lansia (>45 tahun). Pada keadaan ini, terjadi beberapa penurunan daya tahan tubuh atau kesehatan dan perubahan psikologis. Hal tersebut dapat mempengaruhi minat dari responden untuk melanjutkan pendidikan ke perguruan tinggi.

\section{d. Agama}

Hasil penelitian terkait agama guru SMPN di Kecamatan Marpoyan Damai adalah mayoritas Islam, sebanyak 145 orang $(94,2 \%)$. Hal ini selaras dengan penelitian yang dilakukan oleh Purwati (2013) yang menyatakan bahwa agama Islam merupakan agama mayoritas guru di SMPN (86,2\%). 
Menurut Muhaimin (2005 dalam Kosim 2008) ada beberapa istilah guru dalam agama Islam, yaitu ustadz, mu'allim, mursyid, murabbi, mudarris, dan mu-addib. Guru memiliki kedudukan yang istimewa sebagaimana disampaikan dalam dalil naqli yang diriwayatkan oleh Tirmidzi yang artinya "Sesungguhnya Allah, para malaikat, dan semua makhluk yang ada di langit dan di bumi, sampai semut yang ada di liangnya dan juga ikan besar, semuanya bersalawat kepada mu'allim yang mengajarkan kebaikan kepada manusia”. Wahyuni (2014) menyatakan bahwa ada banyak faktor yang menyebabkan seseorang mau menjadi guru, yaitu selain menjadikan guru sebagai profesi untuk mendapatkan uang, banyak juga yang menjadi guru karena panggilan jiwa atau ilahi. Oleh karenanya, peneliti berasumsi bahwa profesi guru merupakan suatu tugas mulia. Selain mendidik, mengajar, membimbing, mengarahkan, dan mengevaluasi peserta didik, guru memiliki kedudukan yang istimewa di dalam agama, sehingga menjadikan profesi ini sebagai salah satu profesi yang banyak diminati.

\section{e. Pengalaman kerja menjadi guru}

Pengalaman seseorang dalam bekerja dapat diperoleh berdasarkan masa kerja, semakin lama bekerja maka pengalaman yang diperoleh akan lebih banyak. Menurut Tulus (1992) masa kerja dapat dikategorikan menjadi tiga yaitu, masa kerja baru ( $<6$ tahun), masa kerja sedang (6-10 tahun) dan masa kerja lama
(>10 tahun). Hasil penelitian menunjukkan bahwa pengalaman kerja menjadi guru pada guru SMPN di Kecamatan Marpoyan Damai Kota Pekanbaru mayoritas adalah lebih dari 10 tahun, yaitu sebesar 110 orang $(71,4 \%)$. Pendapat ini sesuai dengan penelitian oleh Mulyani (2014) yang menyatakan bahwa guru SMPN sebagian besar telah memiliki pengalaman atau masa kerja lebih dari 10 tahun (61\%). Hal yang sama juga dikemukakan oleh Triwulandari (2015) yang menyatakan bahwa mayoritas guru SMP memiliki pengalaman ajar lebih dari 10 tahun $(91,83 \%)$.

Menurut Rida (2013) pengalaman kerja guru sejalan dengan masa kerja yang dimiliki oleh guru, semakin banyak masa kerja yang dimiliki guru tentunya semakin banyak pula pengalaman lapangan yang dimilikinya. Pengalaman guru sangat bermanfaat untuk mengetahui persamaan dan perbedaan anak didik. Tugas guru untuk melayani orang yang beragam memerlukan kesabaan dan ketelatenan yang tinggi, terutama bila berhubungan dengan peserta didik.

\section{Tingkat Pengetahuan Guru SMPN} tentang Bullying di Kota Pekanbaru

Pengetahuan responden tentang bullying diukur dengan 15 pernyataan yang meliputi komponen definisi, karakteristik pelaku dan korban, bentuk, penyebab dan dampak terkait bullying. Hasil penelitian terhadap tingkat pengetahuan guru terhadap lima komponen tersebut, empat komponen diantaranya 
Nurul Wahyuni ${ }^{1}$, Sri Wahyuni ${ }^{2}$, Siti Rahmalia Hairani Damanik ${ }^{3}$, Tingkat Pengetahuan Guru Sekolah Menengah Pertama Negeri tentang Bullying di Kota Pekanbaru

menunjukkan tingkat pengetahuan yang baik, yaitu pada komponen definisi, karakteristik pelaku dan korban, penyebab dan dampak terkait bullying.

Penelitian ini menunjukkan bahwa tingkat pengetahuan guru tentang definisi bullying sebgaian besar adalah baik, sebanyak 107 orang (69,5\%). Hasil ini sejalan dengan penelitian yang dilakukan oleh Kurnia (2017) yang menyatakan bahwa tingkat pengetahuan guru tentang pengertian bullying adalah baik sebanyak 30 orang (85,7\%). Rigby (1996 dalam Astuti 2008) menyatakan bahwa bullying yang terjadi di sekolah memiliki tiga karakteristik yaitu adanya perilaku penyerangan yang sengaja dilakukan, terjadi secara berulang, dan dilakukan oleh orang atau sekelompok orang yang kuat terhadap orang lain. Mayoritas guru mengetahui definisi bullying dengan menjawab benar terkait pernyataan definisi bullying tersebut.

Pengetahuan guru tentang karakteristik pelaku dan korban bullying mayoritas adalah baik, yaitu sebanyak 92 orang (59,7\%). Guru dikatakan memiliki pengetahuan tentang karakteristik pelaku dan korban bullying adalah guru yang mengetahui informasi yang benar terkait karakter pelaku dan korban bullying. Astuti (2008) menyebutkan bahwa pelaku bullying tampak hidup berkelompok, menguasai pergaulan, dan merupakan tokoh populer di sekolah. Adapun karakteristik korban bullying adalah pemalu, pendiam, penyendiri dan sering tidak masuk sekolah karena alasan yang tidak jelas.

Pengetahuan guru tentang penyebab bullying mayoritas adalah baik sebanyak 97 orang $(63 \%)$. Pendapat ini sejalan dengan penelitian oleh Kurnia (2017) yang menyatakan bahwa 22 orang $(62,9)$ guru memiliki tingkat pengetahuan yang baik terkait penyebab bullying. Bullying terjadi tidak hanya disebabkan oleh satu faktor saja tetapi setiap aspek pada lingkungan juga turut memberikan kontribusi baik langsung maupun tidak langsung dalam munculnya perilaku tersebut. Priyatna (2010) dan Tumon (2014) berpendapat bahwa faktor penyebab bullying adalah faktor keluarga, terkait pola asuh orang tua terhadap anak; dan faktor teman sebaya, keikutsertaan dalam kelompok membuat individu merasa diterima.

Pengetahuan guru tentang dampak bullying mayoritas adalah baik sebanyak 73 orang $(47,4 \%)$. Pendapat ini juga sejalan dengan penelitian yang dilakukan oleh Kurnia (2017) yang mengatakan bahwa tingkat pengetahuan guru tentang dampak bullying adalah baik sebanyak 25 orang $(71,4 \%)$. Menurut Rigby (1996 dalam Astuti, 2008) bullying yang terjadi di sekolah tidak hanya dapat menyebabkan kesakitan fisik tetapi juga dapat menyebabkan kesakitan psikologis.

Menurut peneliti, tingkat pengetahuan guru yang baik pada empat komponen terkait bullying yang telah dipaparkan tersebut, dapat dipengaruhi oleh tingkat pendidikan dan 
pengalaman guru dalam bekerja. Tingkat pendidikan guru yang mayoritas adalah pendidikan tinggi memiliki pemahaman dan wawasan yang lebih baik sehingga semakin mudah untuk menerima dan menyesuaikan dengan suatu hal yng baru dalam dunia pendidikan, termasuk terkait bullying. Adapun pengalaman guru dalam bekerja yang mayoritas adalah lebih dari 10 tahun menyebabkan guru lebih banyak melalui proses pembelajaran dan penambahan wawasan baik secara formal maupun non formal dalam dunia pendidikan, sehingga dapat dikatakan semakina lama guru bekerja maka semakin banyak pengalaman dan semakin tinggi pula pengetahuan dan keterampilannya.

Hasil penelitian ini juga menunjukkan tingkat pengetahuan guru tentang bentuk bullying yang sebagian besar adalah cukup sebanyak 57 orang (37\%). Guru dikatakan memiliki pengetahuan tentang bentuk bullying adalah guru yang mengetahui segala informasi terkait bentuk-bentuk bullying. Menurut Priyatna (2010) bullying terbagi menjadi bullying fisik, verbal, sosial dan cyberbullying. Bullying fisik adalah jenis bullying yang kasat mata, siapapun dapat melihatnya karena terjadi sentuhan fisik antar pelaku dan korban bullying. Bullying verbal adalah jenis bullying dengan cara mengolok-ngolok nama panggilan, melecehkan penampilan, mengancam dan menakut-nakuti. Bullying sosial adalah bullying yang berbahaya karena tidak terlihat oleh kasat mata, seperti menyebar gosip. Cyber bullying adalah bullying yang terjadi di dunia maya melalui fasilitas elektronik.

Penelitian oleh Indahyani menyatakan bahwa tingkat pengetahuan guru terkait bentuk bullying adalah rata-rata atau cukup $(74,6 \%)$. Hal yang berbeda disampaikan oleh Kurnia (2017) yang menyatakan bahwa tingkat pengetahuan guru terkait bentuk bullying adalah baik sebanyak 17 orang $(48,6 \%)$. Menurut peneliti, tingkat pengetahuan guru yang cukup terkait bentuk bullying dapat terjadi karena belum adanya sosialisasi khusus terkait bentuk-bentuk bullying terhadap guru-guru di sekolah. Sosialisasi tentang bullying lebih sering dilakukan terhadap peserta didik oleh guru bimbingan konseling. Guru sebagai tenaga pendidik yang melakukan kontak secara langsung dengan siswa tentu harus mengenali bullying dan bentuknya. Pengetahuan guru terkait hal ini sangat diperlukan untuk mendeteksi kejadian bullying di sekolah sehingga dapat diintervensi lebih awal oleh pihak sekolah.

Penelitian ini menunjukkan masih adanya guru dengan tingkat pendidikan yang kurang terkait karkateristik pelaku dan korban bullying (40,3\%) dan tingkat pendidikan yang cukup terkait dampak bullying (46,8\%). Peneliti berasumsi bahwa guru belum sepenuhnya mengetahui terkait karaktersitik dan dampak dari bullying. guru belum 
Nurul Wahyuni ${ }^{1}$, Sri Wahyuni ${ }^{2}$, Siti Rahmalia Hairani Damanik ${ }^{3}$, Tingkat Pengetahuan Guru Sekolah Menengah Pertama Negeri tentang Bullying di Kota Pekanbaru

memiliki informasi yang memadai terkait bullying. Sama halnya dengan pendapat peneliti sebelumnya, hal ini dapat terjadi karena belum adanya sosialiasi khusus terkait bullying kepada guru di sekolah.

\section{Crosstab Tingkat Pengetahuan tentang Bullying berdasarkan Karakteristik Responden}

Berdasarkan karakteristik usia responden, Notoadmodjo (2010) menyatakan usia adalah umur individu yang terhitung mulai dari dilahirkan sampai saat berulang tahun. Usia juga bisa diartikan sebagai satuan waktu yang mengukur waktu keberadaan suatu benda atau makhluk baik yang hidup maupun yang mati.

Hasil penelitian oleh Widawaty (2017) menyatakan bahwa tingkat usia khususnya bagi perempuan untuk bekerja adalah rentang usia 31-35 dan usia diatas 35 tahun. Hal itu dikarenakan rentang usia tersebut merupakan rentang usia yang produktif. Usia produktif merupakan usia dimana seseorang berada pada tahap untuk bekerja/menghasilkan sesuatu baik untuk diri sendiri maupun orang lain.

Hasil penelitian ini menunjukkan bahwa guru yang yang berada dalam rentang usia 3645 tahun sebagian besar memiliki tingkat pengetahuan yang baik. Menurut Maliano dkk (2007 dalam Lestari 2015) usia dapat dikaitkan dengan pengalaman yang didapatkan di tempat kerja. Semakin lama seseorang bekerja sebagai guru maka semakin banyak pengalaman dan

semakin tinggi pengetahuannya dan keterampilannya dalam sebagai tenaga pendidik di sekolah. Namun, guru dengan usia yang relatif muda $(<36$ tahun) dan relatif tua (> 45 tahun) dari rentang usia 36-45 tahun juga ditemukan memiliki tingkat pengetahuan yang baik. Maliano dkk (2007 dalam Lestari 2015) menambahkan bahwa terdapat faktor-faktor lain yang dapat mempengaruhi pengetahuan seseorang yaitu sosial ekonomi, kultur, pendidikan dan pengalaman. Dengan demikian, peneliti mengasumsikan bahwa usia bukanlah satu-satunya faktor penentu tingkat pengetahuan guru terhadap bullying.

Berdasarkan karakteristik jenis kelamin didapatkan bahwa tingkat pengetahuan baik tentang bullying didominasi oleh peremuan, yaitu sebanyak 101 orang $(65,5 \%)$. Hal ini dapat disebabkan karena jumlah responden pada penelitian ini didominasi oleh perempuan. Namun, rasio tingkat pengetahuan baik terhadap jenis kelamin didapatkan bahwa tingkat pengetahuan pada laki-laki (20/33) lebih baik dibandingkan dengan perempuan (101/121) dengan rasio 0,6:0,8. Penelitian yang dilakukan oleh Dale et al dan Theresia et al (dalam Alatas, 2013) menunjukkan bahwa tidak didapatkan hubungan antara jenis kelamin dengan tingkat pengetahuan seseorang. Hal tersebut dikarenakan informasi dari berbagai sumber bisa didapatkan oleh semua orang, baik laki-laki maupun perempuan. 
Hasil penelitian ini menunjukkan jumlah guru pada tingkat pengetahuan kurang pada laki-laki maupun perempuan adalah sama, yaitu sebanyak 2 orang (1,3\%) sedangkan untuk tingkat pengetahuan cukup pada guru laki-laki dan perempuan berturut-turut adalah 11 orang $(7,1 \%)$ dan 18 orang $(11,7 \%)$. Asumsi peneliti, adalah karakteristik jenis kelamin tidak sepenuhnya mempengaruhi tingkat pengetahuan seseorang. Tingkat pengetahuan pada laki-laki maupun perempuan dapat dipengaruhi oleh upaya individu dalam memperoleh pengetahuan dan faktor-faktor lain yang lebih dominan.

Berdasarkan karakteristik pendidikan terakhir, hasil penelitian ini menunjukkan bahwa tingkat pengetahuan guru terkait bullying dalam kategori baik mayoritas adalah pada guru dengan pendidikan tinggi $(74,7 \%)$. Pendidikan tinggi pada guru mencakup program pendidikan diploma, sarjana dan magister. Guru dengan tingkat pengetahuan baik berdasarkan program pendidikan mayoritas adalah Sarjana (68,2\%). Adapun untuk program pendidikan Magister, seluruh guru yang diteliti mempunyai tingkat pengetahuan yang baik tentang bullying $(2,9 \%)$. Berdasarkan data tersebut dapat dilihat bahwa pendidikan dapat mempengaruhi tingkat pengetahuan responden. Hal ini juga sependapat dengan Notoadmojo (2010) yang menyatakan bahwa tingkat pendidikan akan mempengaruhi pemahaman seseorang terhadap suatu pengetahuan, dalam hal ini pengetahuan tentang bullying. Maliano dkk (2007 dalam Lestari, 2015) mengatakan hal yang sama, bahwa tingkat pendidikan seseorang dapat mempengaruhi pengetahuan, dimana semakin tinggi pendidikan seorang guru maka akan semakin mudah untuk menerima, memahami, dan menyesuaikan dengan suatu hal yang baru.

Peneliti berpendapat bahwa tingkat pendidikan seseorang dapat mempengaruhi pengetahuan akan suatu hal, melalui pendidikan seorang guru akan mengenal dan menemukan sesuatu yang baru terkait bidang keguruan. Semakin tinggi tingkat pengetahuan seorang guru maka akan semakin luas pula pengetahuan dan wawasannya, sehingga akan lebih mudah bagi guru untuk mengenali, menerima dan memahami sesuatu yang baru termasuk hal terkait bullying.

Hasil penelitian ini juga menunjukkan bahwa dengan program pendidikan sarjana meliliki tingkat pengetahuan yang kurang terkait bullying (2,6\%). Maliano dkk (2007 dalam Lestari, 2015) mengatakan bahwa tingkat pengetahuan seseorang dapat dipengaruhi oleh banyak hal seperti sosisal ekonomi, kultur dan pengalaman. Asumsi peneliti, guru dengan program pendidikan sarjana merupakan kualifikasi akademik yan sesuai dengan ketetapan Undang-undang Nomor 14 Tahun 2005 tentang Guru dan Dosen sehingga aktivitas dan kegiatan guru dengan kualifikasi tersebut lebih padat dibandingkan dengan guru yang belum 
Nurul Wahyuni ${ }^{1}$, Sri Wahyuni ${ }^{2}$, Siti Rahmalia Hairani Damanik ${ }^{3}$, Tingkat Pengetahuan Guru Sekolah Menengah Pertama Negeri tentang Bullying di Kota Pekanbaru

mencapai kualifikasi akademik. Hal ini didukung oleh pernyatan dari masing-masing Wakil Ketua bagian Humas dan Kurikulum di SMPN yang menyatakan padatnya aktivitas guru di sekolah. Hal ini dapat memengaruhi konsentrasi dan fokus guru dalam mengisi kuesioner penelitian.

Berdasarkan karakteristik agama, penelitian ini menunjukkan bahwa tingkat pengetahuan yang baik tentang bullying didominasi oleh guru beragama Islam $(74,7 \%)$. Maliano dkk (2007 dalam Lestari, 2015) mengatakan bahwa pengetahuan sesorang mengenai suatu hal dapat dipengaruhi oleh faktor kultur (agama dan budaya) karena informasi yang diperoleh akan disaring sesuai atau tidaknya dengan agama dan budaya yang dianut. Berdasarkan rasio tingkat pengetahuan guru terhadap agama didapatkan bahwa guru beragama Islam dengan pengetahuan baik tentang bullying (115/145) dengan guru beragama Kristen berpengetahuan baik (6/9) adalah sebesar $0,7: 0,8$. Hal ini menandakan bahwa tidak terdapat perbedaan yang signifikan antara agama guru terhadap pengetahuan tentang bullying, sehingga peneliti berasumsi bahwa semua agama memiliki pandangan yang sama dan tidak membenarkan bullying.

Berdasarkan karakteristik pengalaman kerja menjadi guru, pembahasan hasil penelitian adalah sebagai berikut. Knoers dan Haditono (1999 dalam Asih 2006) mengatakan bahwa pengalaman merupakan suatu proses pembelajaran dan penambahan perkembangan potensi bertingkah laku baik dari pendidikan formal maupun non formal atau bisa juga diartikan sebagai suatu proses yang membawa seseorang kepada suatu pola tingkah laku yang lebih tinggi. Lestari (2015) mengemukakan bahwa pengalaman adalah sesuatu yang pernah dilakukan seseorang yang akan menambah pengetahuan tentang sesuatu yang bersifat informal.

Penelitian ini menunjukkan bahwa tingkat pengetahuan guru SMPN kategori baik tentang bullying sebagian besar dimiliki oleh guru dengan pengalaman kerja lebih dari 10 tahun. Lestari dan Maliano dkk (2007 dalam Lestari, 2015) berpendapat bahwa pengalaman merupakan salah satu faktor yang dapat mempengaruhi pengetahuan seseorang. Maliano dkk (2007 dalam Lestari, 2015) menambahkan bahwa pengalaman seseorang berkaitan dengan umur dan pendidikan individu. Pendidikan yang tinggi, maka pengalaman akan lebih luas, sedangkan semakin tua umur seseorang maka pengalamannya akan semakin banyak. Hal ini di dukung oleh Mulyanti (2009 dalam Utomo, 2015) lama kerja seseorang dapat dikaitkan dengan pengalaman yang didapatkan di tempat kerja. Semakin lama seseorang bekerja semakin banyak pengalaman dan semakin tinggi pengetahuannya dan keterampilannya. Peneliti berpendapat bahwa guru yang mempunyai pengalaman mengajar lebih lama akan semakin banyak dan bervariasi dalam 
melaksanakan tugas mengajar dan mendidik. Semua pengalaman tersebut akan menambah pengetahuan dan keterampilan guru dalam melaksanakan tugas sebagai tenaga pendidik di sekolah.

\section{PENUTUP}

\section{Simpulan}

Penelitian yang dilakukan terhadap guru SMPN tentang tingkat pengetahuan terkait bullying didapatkan bahwa pengetahuan guru tentang pengertian bullying adalah baik sebanyak 107 orang (69,5\%), karakteristik pelaku dan korban bullying adalah baik sebanyak 92 orang $(59,7 \%)$, bentuk bullying adalah cukup sebanyak 57 orang (37\%), penyebab bullying adalah baik sebanyak 97 orang (63\%), dan dampak terkait bullying adalah baik sebanyak 73 orang $(47,4 \%)$. Hasil penelitian juga menunjukkan bahwa dari 154 orang responden, mayoritas tingkat pengetahuan guru SMPN tentang bullying adalah baik sebanyak 121 orang $(78,6 \%)$, tingkat pengetahuan cukup sebanyak 29 orang $(18,8 \%)$ dan tingkat pengetahuan kurang sebanyak 4 orang $(2,6 \%)$.

\section{SARAN}

Bagi guru sebagai tenaga pendidik agar dapat menjadi gambaran untuk meningkatkan pengetahuan dan upaya pencegahan serta penanganan bullying dengan berpartisipasi aktif dalam sosialisasi atau seminar khususnya terkait bentuk bullying di sekolah. Selain itu, diharapkan guru memiliki kualifikasi sesuai dengan peraturan perundang-undangan yang berlaku. Bagi institusi pendidikan dapat membuat suatu seminar terhadap guru untuk senantiasa mempertahankan dan meningkatkan pengetahuan terkait bullying dan memberikan penghargaan terhadap guru yang mampu untuk mendeteksi dan merespon perilaku bullying di sekolah.

\section{DAFTAR PUSTAKA}

Arya, L. (2018). Melawan bullying: Menggagas kurikulum anti bullying di sekolah. Mojokerto: CV Sepilar Publishing House.

Asih, D. (2006). Pengaruh Pengalaman terhadap Peningkatan Keahlian Auditor dalam Bidang Auditing. Skripsi. Falkultas Ekonomi Universitas Islam Indonesia. Yogyakarta

Astuti, P. R. (2008). 3 Cara meredam bullying. Jakarta: PT Gramedia Widasarana Indonesia.

Coertse, \& Schepers. (2004). Some Personality and Cognitive Correlates of Career Maturity. Journal of industrial Psychology. 30(2), 56-73. Afrikaans University. www.researchgate.net

Departemen Pendidikan Nasional. (2003). Undang-Undang No. 20 Tahun 2003, Tentang Sistem pendidikan Nasional. Jakarta: Depdiknas.

Departemen Pendidikan Nasional. (2005). Undang-Undang No. 14 Tahun 2005, Tentang Guru dan Dosen. Jakarta: Depdiknas.

Departemen Pendidikan Nasional. (2008). Kamus Bahasa Indonesia. Jakarta: Depdiknas.

Dwipayanti, I. A. S., \& Indrawati K. R. (2014). Hubungan antara tindakan bullying dengan prestasi belajar anak korban bullying pada tingkat Sekolah Dasar. Jurnal Psikologi Udayana, 1(2), 
Nurul Wahyuni ${ }^{1}$, Sri Wahyuni ${ }^{2}$, Siti Rahmalia Hairani Damanik ${ }^{3}$, Tingkat Pengetahuan Guru Sekolah Menengah Pertama Negeri tentang Bullying di Kota Pekanbaru

251-260. Diperoleh tanggal 10 Oktober 2018 dari https://ojs.unud.ac.id.

Handoyo, T. (1992). Minat mahasiwa IKIP terhadap profesi guru ditinjau dari jenis kelamin, daerah asal, profesi orang tua dalam hubungannya dengan prestasi belajar. BPPS UGM, 5(2A). Diperoleh tanggal 19 Februari 2019 dari ilib.ugm.ac.id

Indahyani, F. (2015). Pengetahuan guru tentang bullying. Jurnal Psikologi. Universitas Muhammadiyah Purwokerto. jurnalnasional.ump.ac.id

Kosim, M. (2008). Guru dalam perspektif islam. Jurnal pendidikan Islam, 3(1). Diperoleh tanggal 8 Maret 2019 dari http://ejournal.stainpamekasan.ac.id

Kurnia, D. (2017). Gambaran pengetahuan guru tentang perilaku bullying pada anak Sekolah Dasar di Desa Karangtengah Kecamatan Baturraden Kabupaten Banyumas. Universitas Muhammadiyah repository.ump.ac.id

Lestari, T. (2015). Kumpulan teori untuk kajian pustaka penelitian kesehatan. Yogyakarta: Nuha Medika

Maliki A. E., \& Asagwara C. G. (2009). Bullying problem among school children. Journal Of Human Ecology, 25(3), 209-213. Diakses tanggal 13 Oktober 2018 http://citeseerx.ist.psu.edu

Mulyani, S., \& Soliha, E. (2014). Pengaruh karakteristik pekerjaan dan motivasi terhadap komitmen organisasional serta dampaknya terhadap kinerja guru. Jourrnal of performance, 20(2), 46-71. Diperoleh tanggal 23 januari 2018 dari jp.feb.unsoed.ac.id

National Bullying Prevention Center. (2017). Bullying statistic. Diakses tanggal 10 Oktober 2018 dari https://www.pacer.org

Notoadmodjo, S. (2010). Promosi kesehatan teori \& aplikasi. Jakarta: Rineka Cipta

Novianto, R.D. (23 Juli 2018). Catatan KPAI bidang pendidikan: Kasus bullying paling banyak. Sindonews.com Diperoleh tanggal 21 Oktober 2018 https://nasional.sindonews.com.
Nugroho. (Juni, 2011). Program psikoedukasi untuk meningkatkan pengaturan dan keterampilan guru dalam megangani bullying. Jurnal Intervensi Psikologi, 3(1). Program Profesi Psikologi Universitas Gadjah Mada Yogjakarta. Diperoleh tanggal 16 Oktober 2018 dari http://jurnal.uii.ac.id.

Nurridha, L. (2017). Kasus bullying meningkat, pelaku didominasi oleh remaja. Kumparan.com. Diperoleh tanggal 25 Oktober 2018 dari https://kumparan.com/.

Purwati, N. (2013). Hubungan sikap guru tentang pendidkan seks pada remaja dengan penerapan pendidikan seks di SMPN 1 Pajangan Bantul. Sekolah Tinggi Ilmu Kesehatan 'Aisysyiah. http://digilib.unisayogya.ac.id

Pusat Data dan Statistik Pendidikan dan Kebudayaan. (2017). Indikator Pendidikan. Diperoleh tanggal 19 Februari 2019 dari http://sdm.data.kemdikbud.go.id

Pusat Data Statistik Pendidikan dan Kebudayaan. (2018). Statistik Pendidikan. Diperoleh tanggal 22 Januai 2019 dari http://statistik.data.kemdikbud.go.id/

Priyatna. A. (2010). Let's End Bullying. Jakarta: PT. Elex Media Komputerindo, Gramedia

Putri, A.S, (10 Juli 2018). KPAI: Bullying pada anak di media sosial semakin meningkat tiap tahunnya. Vemale.com. Diperoleh tanggal 21 Oktober 2018 dari https://www.vemale.com/.

Putri, N. H., Nauli, F. A., \& Novayelinda, R. (2015). Faktor-faktor yang berhubungan dengan perilaku bullying pada remaja. Jurnal Online Mahasiswa, 2(2), 11491159. Diperoleh tanggal 31 Oktober 2018 https://media.neliti.com/

Rida, M. (2013). Hubungan motivasi kerja, masa kerja dan kesejahteraan guru terhadap profesionalisme guru Sekolah Dasar Negeri di Gugus II Kecamatan Sukasada. Jurnal Pendidikan dasar Indonesia, 3 (1). Diprtoleh tanggal 10 Maret 2019 dari 
http://119.252.161.254/e-

journal/index.php

Saptandari, E.W. \& Adiyanti, M.G. (2013).

Mengurangi perilaku bullying melalui program Pelatihan Guru Peduli. Jurnal Psikologi Universitas Gadjah Mada, 40(2), 193-210. Diperoleh tanggal 15 Oktober 2018 dari https://journal.ugm.ac.id.

Smokowski, K. (2010). Bullying in shool: an overview of type, effect, family characters, intervention strategies. Children and School Journal. Diperoleh tanggal 22 Oktober 2018 dari https://academic.oup.com

Soedjatmiko., Nurhamzah, W., Maureen, A. \& Wiguna, T. (2013). Gambaran Bullying dan Hubungannya dengan Masalah Emosi dan Periaku Anak Sekolah Dasar. Jurnal Sari Pediatri, 15(3). Diperoleh tanggal 15 Oktober 2018 dari https://saripediatri.org.

Sugiariyanti. (2010). Perilaku bullying pada anak dan remaja. Jurnal Psikologi Ilmiah, 1(2). Semarang: Program Studi Psikologi Fakultas FIP UNNES.

Sugiyono. (2011). Metode penelitian pendidikan. Bandung: Alfabeta.

Sumakta, I. A. (2015). Pengaruh prestasi belajar, pendapatan orang tua, ekspektasi kerja terhadap minat melanjutkan studi ke S2 pada mahasiswa Pendidikan Ekonomi FE UNY. Universiats Negeri Yogjakarta. https://eprints.uny.ac.id

Surilena. (2016). Perilaku bulying (perundungan) pada anak remaja. Jurnal Kedokteran Universitas Katolik Atma Jaya. Diperoleh tanggal 23 Oktober 2018 dari http://www.cdkjournal.com.

Susanti, R., Ifroh, R.H., \& Wulandari, I. (2018). Mapping school bullying pada anak di kota samarinda dengan Epi Map. JPH Record, 1(2). Diperoleh tanggal dari http://journal.unair.ac.id.

Triwulandary, A. (2015). Sikap guru terhadap penerapan program inklusif ditinjau dari aspek guru. Jurnal Pendidikan dan Pemberdayaan Masyarakat, 2(2), Diperoleh tanggal 22 Januari 2019 dari journal.uny.ac.id
Tulus, M Agus. (1992). Manajemen Sumber Daya Manusia : Buku Panduan Mahasiswa. Jakarta : PT Gramedia Pustaka Utama

Tumon, M. B.A. (2014). Studi deskriptif perilaku bullying pada remaja. Jurnal Psikologi. Diperoleh tanggal 19 Oktober 2018

dari http://www.journal.ubaya.ac.id.

Utomo, N. (2015). Hubungan tingkat pengetahuan risiko penyakit akibat kerja dengan kesadaran pemakaian masker pada pekerja bagian operator jahit $C V$. Maju Abadi Garment Sukoharjo. Universitas Muhammadiyah Surakarta. http://eprints.ums.ac.id

Usman, I. (2013). Perilaku bullying ditinjau dari peran kelompok teman sebaya dan iklim sekolah pada siswa SMA di Kota Gorontalo. Gorontalo: Universitas Negeri Gorontalo.

Wahyuni, S. (2014). Profesi guru adalah panggilan Ilahi. Jurnal Teolgi dan Pelayanan, 3(5). Diperoleh tanggal 10 Maret 2019 dari http://sttintheos.ac.id

Widawaty, Z., \& Elvina, W. (2017). Kualitas perempuan pekerja di kota lhokseumawe. Jurnal Ekonomi dan BIsnis Indonesia, 1(1), 40-47. Diperoleh tanggal 22 Januari 2019 dari http://ejurnal.pnl.ac.id

Yayasan Semai Jiwa Amini (SEJIWA). (2008). Bullying: Mengatasi kekerasan di sekolah dan lingkungan sekitar anak. Jakarta: PT Grasindo. 